\title{
UNDERSTANDING GOD IN FOLKLORE DISCOURSE: SEMANTIC OPPOSITIONS
}

\section{Matskiv P. V.}

\section{INTRODUCTION}

In the folklore discourse, the understanding of God is objectified in the cultural, mythological, ontological, cosmological, and religious strata which, in a synthesized form, compose the paradigm of the people's understanding of the Absolute. The Ukrainian ethnos, its ancestors are characterized by the evolution of religious views, and they reflect segments of these strata. Significant semantic differences in legends, carols, phraseological constructions regarding the explication of the conceptual characteristics of the sacrum sphere are traced. Different semantic-cultural oppositions are objectified in phraseological structures with the God component. Differences are also observed on the diachronous axis of coordinates. Binary oppositions usually refer to the early period of ethnogenesis of the Ukrainian people, dualism in the transcendental sphere at later stages of development undergoes modifications towards monotheism, although elements of monogenism, animism, totemism, pantheism are preserved in the Ukrainian language.

The folklore discourse, a sacred one in particular, is in the field of view of scholars of different eras (historians, ethnographers, literary critics, linguists). Among the researchers, a significant trace has been left by O. Potebnia, I. Franko, M. Drahomanov, M. Kostomarov, I. NechuiLevytskyi, P. Chubynskyi, H. Bulashev, L. Niderle, B. Rybakov, B. Hrinchenko, M. Hrushevskyi, I. Ohiyenko, V. Hnatiuk, S. Kylymnyk, O. Voropai, D. Antonovych, Khv. Vovk, P. Zhytetskyi, P. Kulish, M. Maksymovych, I. Sreznevskyi, M. Sumtsov and others. At the present stage, the achievements of folklorists and philologists are significant in the outlined realm (M. Dmytrenko, P. Kononenko, M. Lanovyk, Z. Lanovyk, H. Lozko, O. Myshanych, L. Dunayevska, S. Myshanych and others).

Ukrainian phraseology and paremiology reflect popular beliefs about God, which testify to the evolution of religious views of Ukrainians: polytheism, the court, monotheism (Christianity). These religious manifestations coexist in some way in the popular consciousness, creating a religious picture of the world of Ukrainians. In the monograph, we consider religious ethno-consciousness in the context of cultural and historical oppositions - God's qualities / human qualities, God / gods. 


\section{Semantic opposition to God / man in small folklore genres}

The qualities of God are transmitted both in the transcendental and immanent dimensions. The sacrum and profanum spheres interact with each other in terms of additional distribution or transitivity. The sacral sphere is represented at the level of the object-centric code by such predicates: svyatyy, myloserdnyy, vsemohutniy, vsevydyushchyy, dyvnyy. The power of God is manifested through His heavenly or earthly actions: $y$ Бога все мога (12, 40), Господь усьому корма (6,435), Господь усім токма (6,435). The phrase дивен єси Господи! $(6,435)$ correlates in a certain way with the biblical account of Moses' request to the Lord to show his face, the radiance of which was so striking that Moses exclaimed, "You are wonderful, Lord!" In it, God emerges as the creator of the miracles, revealing one of the greatest and most intimate signs of God peculiar to Him alone. The mercy of the Lord, compassion, isotopes with the principles of ecumenism (нехай Бог милує усякої віри! $(12,375)$ Біг не наnacmb $(6,26)$, and the criterion of value is freedom of choice, not coercion that constrains the human will. The influence of the biblical picture of the world on folklore is observed in the functioning of phrases that correlate with Scripture.

The human will, on the one hand, is dependent on God, reflected in the paremias: то Божа воля, чи щзаслива чи нещасна доля (12, 587), най сї діє Божа волї! (6,256), здай сї на Господа милосердного (6,435), на Господа вся надїя $(6,436)$. Man, relying on this approach, relies only on God - всьо на божу волю здай (6,282), а щзо ж робить! На те воля Божа $(12,141)$. On the other hand, by his actions, useful work, and mental activity, man solidifies with God's instructions, thus approaching God. This thought dominates the folklore discourse (Боже поможи, а ти небоже не лежи (6,131), Бога взивай, а руки прикладай (6, 32), Богу молись, а до берегу гребись (12, 43), Богу молись, а сам сбережись $(12,41)$, роби небоже, то й Бог поможе $(12,42)$, на Бога складайся, розуму ж тримайся $(12,41)$. The supremacy of God, His difference from earthly traditions is expressed by superstitious imperatives that regulate both spiritual and material spheres of activity, with God's characteristics appearing as absolute (peculiar only to Him) - Бог ніколи не дрімає (6,90), Бог не спить $(6,87)$, Бог не бреше $(6,82)$. The distance between God and man is verbalized by a system of "recommendations" based on binary oppositions inherent in man but not God: Бог жартів не любит

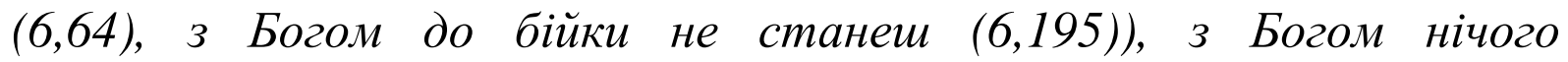
жартовати (12, 42), силою Бога не взяти $(12,40)$, на Бога не дуже гримай $(12,40)$, Бога не тра вчити $(6,37)$. These reservations become understandable and motivated by another group of phraseological 
constructions explicating the transcendental qualities of God (Бог все бачить (12, 41), перед Богом нічого не втаїти (6,300), од Бога нігде не сховаєшся $(12,41)$, Бога всюди найдеш $(6,33)$.

Monotheism as the basis of the Christian worldview is fixed in the stable compounds that characterize God and His creation through the prism of absolute categories of oneness, eternity, ignorance of God and His truths: над Богом нема нікого $(12,39) ;$ усе тінь минуща: одна річ живуща - світ з Богом (12, 56), ніхто не знає о Божім світі (12, 56), yсi ми під Богом $(12,39)$. Believing in God is the duty of the Christian, although not only is faith enough, good things are needed too. Sometimes paremias reflect a certain skepticism about belief in God, faith in a person, which, however, is not generally characteristic of the people's outlook (вip Богу тай свойм очам, тай то не дуже $(6,224)$.

Divine qualities in phraseological units are transmitted through the human ones, though, of course, they are not identical with them, because "Бог суде не так як люде" (12, 40). God's knowledge about the created world, its spatial and temporal characteristics (we mean here primarily the primary process of phrase-making) is the most explicit: Бог знає, один Бог знає, Бог зна що, Бог знає поки, Бог зна куди, Бог зна як. The above mentioned phrasal units have acquired signs of contradictoriness (the first three) with potential convertibility as a result of the secondary nomination, since these phrasal units can function as free syntactic constructions. Phraseologisms Бог знає поки, Бог знає куди, Бог зна як have acquired the integral seme "unknown" in the process of secondary semantization deactualizing their procedural semes and accordingly activating local, temporal, and spatial ones. In our opinion, the processual semes in the above mentioned phrasal units, as well as the archiseme God, are not lost, although at the secondary level they have the categorical seme with the corresponding specifiers of place, time, and method. As the primary formations, these constant compounds are no different in functional terms from the previous ones.

The syntactic constructions that fully convey the analyzed quality of God testify in support of our assumption (Бог то святий знає, щуо з того буде (12, 354), Він знає, що починає (12, 40), Бог те знає, а не ми грішні $(12,40)$, Господь знає, але ніколи не скаже $(6,434)$. The paremia that objectifies God's concern for each person is indicative in this respect знає Біг з неба, щзо кому треба. Even in misery, one should not despair, but live with the thought that God has sent evil upon them for their own good.

God acts as absolute volodar vlady, syly, voli, blahodati: Божа воля, Божа власть, Божа сила $(12,141)$. He is the only just judge in heaven and earth (сильного рук Бог один судить $(12,83)$, who forgives (Бог не 
без милости, козак не без щуастя (12, 233), Бог милував (13 I, 37), sees everything (од Бога ніде не сховаєшся $(12,41)$, is the creator and provider of earthly and heavenly goods (Бог дав; Бог дає (13 I, 36). The best human traits are embodied in God: Бог батько, господар, дядько (12, 41), Бог - батько: як буде нас тримати, то й буде годувати $(12,42)$. The Lord is Almighty (y Бога все мога, у Бога все готово $(12,40)$, з одним Богом на сто ворог $(12,39)$. The path to God lies in the high spiritual qualities commanded by God that give life to God: від серия доБога навпростещь дорога (12, 42), хто з Богом, з тим Бог (12, 42), через Святих до Бога $(12,44)$. High spiritual (Christian) virtues are the key to life's benefits: якщо будеш угоден Богу, то не будеш і голоден (12, 632); будь лагодним, будеш і Богу угодним (12, 227), щиирому і Бог nомагає $(12,220)$. The grace of God defines the paradigm of human existence without dividing people into the poor and the rich (кому Бог поможе, то все переможе $(12,39)$. The dominance of God in all things is evident: чоловік мислить, а Бог радить $(12,42)$.

God as the Giver (the Giver) personifies the earthly structure in the past, present and eschatological dimensions (Що було, то бачили, що буде, побачимо, - а буде те, що Бог дасть (12, 41). Man and the universe are subordinate to God (як не ради, а не буде так, як ти хочеш, а так буде, як Бог дасть $(12,89)$ and coordinated with Him. The Lord, as the submitter, is especially generous in giving thanks for diligent work and for patience (Бог за праиу маєть щзось дати (12, 42), за потерпінням дасть Бог спасіння $(12,141)$. God cannot be subjective, His distribution is just: єдному Бог дасть ситие, а другому решітие (12, 124), за перебір дасть Бог витрешки (12, 228), як ми до Бога, так Бог до нас (6,378). All of God's actions are directed toward goodness, even when the Lord deprives: (що Бог дає, то все к луччому (12, 41), щзо Бог дасть, то не напасть (12, 41); Бог дав, Бог і взяв (12, 118). There is nothing impossible for God - Бог дасть долю $і$ в чистім полю (12, 123), Бог дасть и в печі не замажесся $(12,132)$. Distress and misfortune is given by God for the test (котрий Біг засмутив, той потішит (6,233), на лихо Бог дасть толк $(12,125)$.

God's love, on the one hand, extends above all to an honest and kind man, though very often God sends misery to this person, trying and tempering his character. (кого Бог любить, того не загубить (6, 221); кого Бог любить, того карає (12, 40), делюбов, там сам Бог перебуває $(12,422)$. The aforementioned paremia is a peculiar formula of love in both transcendental and immanent ways, and it reflects, in essence, the divine nature of love. The trinity of God's hypostasis is correlated with the other canonized saints of Christianity - Our Lady, Savior. In doing so, 
a distinction is made between a saintly/ holy person and the time, which indicates a peculiar categorization of the religious continuum. Hope in God, his mercy, compassion is isotoped with the activity of man: надія в Бозі, як є що в возі (12, 693); не все од Бога: треба й до розуму свого $(12,581)$. Binary opposition theocentrism - anthropocentrism is divided into separate spheres (щุо Богу, то Богу, ащсо людям, то людям $(12,531)$, which correlate with the biblical ones - кесареві кесареве, Богові Боже.

In semantic opposition, God / man an important place is occupied by the relationship between God and man, more precisely, the projection of God into man through the prism of dualistic characteristics of the latter (opposition sacral / profane, good / evil, positive / negative). The ideal essence of the man of God is objectified by his spiritual virtues, the defining of which are: righteousness, truthfulness, justice (праведного чоловіка і Бог оправдав (12, 311), справедливого чоловіка то й Бог любить (12, 311), хто по правді жиє, то й Бог дає (12, 311). Relations between God and man are based primarily on God's commandments, then they become harmonious and justify the earthly life of man: за ким Біг, за тим і люде (6,193), хто против Бога, то Бог против него $(6,339)$. The recorded paremias testify to an anthropomorphic understanding of God: a sinful, ungodly man cannot count on God's intercession or condescension, but this does not contradict the idea of equality of people before God, their free choice to serve God. In paremias reflected biblical understanding of the purpose of hypostatic entities: Біг Богом, а люди людьми (6,14), щуо Богу, то Богу, а щзо людям, то людям (12, 531). Violation of such separation, even within the coordinate axis of the "person" is strongly condemned, for example: не дай, Боже, з хама пана $(12,97)$, не дай, Боже, з Ивана пана $(12,97)$, it emphasizes both social status and personal traits of a person. This implies a certain categorization of the activity aspects of God and man, for "не все ж Бог дарує, про що люд міркує" $(12,42)$, moreover, the person does not act as a passive observer (Бог нерівно ділить: жде, щоб самі ділилися $(12,42)$, and the "roles" are clearly divided, the coordination of God over man is evident (чоловік крутить, а Бог розкручує $(12,42)$, чоловік стріляє, а Біг кулі носить $(12,42)$, чоловік думає, а Бог умає $(12,621)$. The help of God to man guarantees him the achievement of the goal, at God's perception of man nothing is scary (кому Біг поможе, той все переможе $(6,229)$, з одним Богом на сто ворог (12, 39), diverting God's attention can lead to a fatal outcome that, except God, no one can change (нixmo mozo не наверне, від кого ся Бог відверне $(6,281)$. Enfringement on someone 
else's possession cannot be forgotten: here God's retribution is sure to become a fact.

The idea of sinfulness is a kind of dividing line between God and man. As you know, sin is introduced by man, not by God (всі-смо в Бога грішні $(6,463)$, один Бог без грiха $(12,339)$ and you cannot hide it before God. The suffering of God before human sins is not infinite, but not always instantaneous (терпит Бог нашим гріхам, доки терпит (6, 460), Бог довго жде, та й кріпко карає $(12,621)$. Thus, for the sins of youth, the payment comes in old age: карає Бог старі кости за гріхи в молодости $(6,216)$; children, grandchildren, great-grandchildren are responsible for the sins of their parents (Пан Біг сі і триціть років упоминає (6, 294). The paremias also present visions of the punishment of God other than human (Бог не трубить, коли чоловіка губить (12, 41); God does not punish like the man does (Бог не карає месков, але ласков $(6,89)$; кого Бог укарати хоче, тому и розум відбере (6, 225); Бог не карає прутом $(6,84)$. His punishment is very often a test for a person who is set on good deeds. For the harm done to the community, a double punishment of God awaits man: за громадське Бог дубельт карає (6, 467), громадської кривди Бог не подарує (6,467). On the one hand, in paremic units, there is a superficial attitude towards sin, as to obvious things that do not require any spiritual effort. (Гріх не гріх, аби Бог простив (12, 43), як не прийме Біг гріхи за жарт, то буде шелесту багато $(12,43)$; on the other hand, sin is considered objectively, and a person will necessarily be responsible for his or her actions (sins): Біг гріхом карає $(12,43)$. The source of $\sin$ is the devil (Не гріши на Бога - чорт гріхи забрав $(12,82)$.

In the semantic opposition of God/man, the attitude of God to man as the bearer of certain traits or activities through the system of binary oppositions of good / evil, positive / negative, is quite widely represented. God's attitude to father is special (omeub - як Бог $(12,12)$, as well as to the host (хазяїна і Бог любить (12, 449), traveller (подорожнему и Бог вибачає $(12,501)$, orphan, although, there is some contradiction here, on the one hand, за сиротою Бог з калитою $(12,474)$, and on the other one - Бог сиріт любить та щастя не дає $(12,474)$. The relationship of God with the guest is marked by care, patronage (2icms в дім, Бог з ним (6,333). The hospitality display is an old-fashioned custom in which the guest was offered all the best that was in the house. Customary law requires the guest to have a good meal (everything the house is rich in). The sincerity of the guest should be shown not only by expressions of external attention, but also by dishes. Therefore, it is not surprising that it was the joy of all the family members, because then they had "something" (нанеси Бог гостя, то йхазяїну добре (12, 518), коли б дав Бог гостя, 
то й ми б поживились коло гостей $(12,518)$, принеси, Боже, здалека родину, то ми и в будденє зробимо недільо $(12,517)$. When a guest stayed for a long time for no apparent reason, his attitude changed to the opposite, and after the guest left the house (най вас Бог щасливе провадить и в найбільше болото посадить (12, 521), ой, Боже, Боже, ци мав ти коли гості? $(6,286)$. The guest of God becomes a man who finds refuge from danger in the temple and takes the throne. From now on, he cannot be brought to justice. This habit has been known since the Old Testament (3 Цар.1; 50-51) and has passed into the Christian temple. God's protection, intercession extends above all to the people who do good, are marked by sincerity, gentleness, caution (будь людям добрим угоден, будеш и Богу надобен $(12,220)$, щирому и Бог помагає (12, 220), будь лагодним, будеш и Богу угодним (12, 220), береженого и Бог береже $(12,215)$. These people are in God's care, but sometimes they die at a young age, which, according to popular beliefs, is explained as follows: Пан Біг що ліпше собі забирає $(6,297)$. This view is a manifestation of deep folk wisdom (calming in misery, a kind of healing of wounds), but has no connection with Christianity. Pride as a trait of a person's character is one of the most negative and incompatible with God: гордому Бог сі противит (6, 12), гордим Бог позбива (12, 142), гордим Бог роги пощибає $(6,12)$. In the last paremia, the horn symbolizes pride and is taken from the ancient Christian apocalyptic literature of the first centuries of Christianity, although the horn in the Bible symbolizes power, authority, and word. The peculiar manifestation of God's negation of man relates primarily to the idle, drunkards. Yes, a nerd "в Бога день краде $(6,140)$, his fate seemed to be of no interest to God (ледачого Бог не візьме $(12,519)$, though the fate of the nerd is not so unhappy, because “лежухові Бог долю дає” (12, 350). Behind another paremia (гній лежит, а Бог долю держит $(6,350)$, the fate of the nerd is sometimes happy. There is a stylization of a parable under the biblical story of Jesus Christ, seeing a lazy slumber lying under a pear-tree and waiting for it to fall into the mouth, nevertheless He awarded him with a hardworking and obedient girl for his wife.

A fool has custody from God ("дурневі Бог щуастя дає (12, 292), дурному и Бог простить (12, 292), sometimes this guardianship looks quite partial (дурному дасть Бог щастя, а не дасть розуму $(12,292)$, дурневі и Бог не противиться $(12,292)$. In the paremias, the negative attitude of God towards fools prevails, which is euphemistically expressed (создав Бог, та й раскаявся (12, 380), создав Бог та й ніс висякав! (12, 294); ironic-sarcastic (дурень воду носе, дурна Бога просе, гори хата ясно, щуоб ти не погасла $(12,299)$. The thought of a fool for God is 
not simply something that is of no value (чи Бог дитина дурнів слухати (12, 208), Бог не дитина, аби слухав дурного Клима $(6,292)$, but also offensive to some extend. Negative traits of man are equally condemned by God and by people objecting to proverbs: ані до Бога, ані до людий $(6,8)$ or are personified by human names (з Богом, Парасю; з Богом, Марусю, по морозию! (12, 242), пустив Бог Микиту на волокиту (12, 129).

In the semantic opposition to God/family relationships, a special role is given to the woman. The union of man and woman is established in heaven (смерть ажена від Бога призначена (12, 400), and only a monogamous marriage is acceptable to God,oскільки "перша жінка од Бога, друга од людей, а третя од чорта (12, 400). Faithfulness in marriage is a defining commandment of God; although this allegiance is sometimes violated by the male gender: Бог зажінку, а чоловік за дівку $(12,7)$, Бог за одну, а чоловік за другу $(12,7)$. Yet the sympathy of God is on the man's side: и так багато всякого лиха, а Бог ще жінок наплодив (12, 401), не квапся женитися, бо ще тобі жінка стане костію в горлі - ї̈ Бог сотворив з кості $(12,392)$. A similar argument is made in one of the following points: "Чому Бог не сотворив Сви з ноги Адама? щоб жінка по корчмах не ходила; чому не з руки? щоб мужа за лоб не дерла; чому не з голови? щуоб не була розумніша од мужа, але з ребра, щзоб его пильнувала и ему вірно служила" $(12,401)$. This version of family relationships is fundamentally different from the Christian understanding of family, by which husband and wife form spiritual unity, equal before God, but have different tasks.

In our opinion, the young / old dichotomy about God is categorized in a peculiar way: the promotion of the young and the lack of assistance to the old, which is expressed in emotional rather than essential expressions (дітям Бог подушки стеле, а старому хоч би соломки підослав (12, 12); як дитина падає, то Бог подушку підстилає, а як наш брат (старий) упаде, то або на драбину, або на граблі $(12,12)$.

The semantic opposition of God / witchcraft explicates the power of

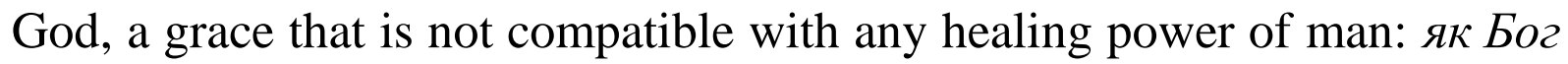
поможе, то й баба поможе (12, 377), Бог з помоччю, а баба з руками (12, 377), баба з річчю, Бог з поміччю $(12,377)$.

The relationship of man with God is not always correct, bordering on familiarity, spirituality, apathy (дай, Боже, наперед більше! (12, 529), Боже, поможи, отут і положи! (12, 44); прости, Боже, сей раз та ще десять разів: а там побачимо (12, 44); Боже, дай добре, та не довго ждати $(6,124)$ etc., but in general they are not characteristic of the phraseological picture of the world. 
In the semantic opposition, God / man's death does not observe a clear differentiation of physical (natural) and spiritual death as eternal communion with God, though man's death and actions are interdependent (не Бог на смерть веде, сам чоловік іде $(12,323)$. In the request of God, death is objectified as a physical entity: дай, Боже, вмерти, та не під плотом; не дай, Боже, звалиться під тином (12, 372); Боже, як прийде час умерти, не допускай довго лежати - кажи прийти смерти! $(12,372)$ as well as a spiritual one: дай, Боже, на тім світі побачиться (12, 521), всі смо гостї на божім сьвіті $(6,186)$. The fear of physical death is conveyed by euphemistic expressions: на Божій дорозі (8 I, 81), Господь прийняв душу (12 I, 37), Божа постіль $(8 \mathrm{I}, 81)$, нехай з Богом спочиває $(12,521)$. Death is appointed by God and does not depend on man (смерть ажена від Бога призначена (12,400); як напише Бог смерть на роду, то не обійдеш и наледу $(12,604)$, on the other hand, the attitude to death is viewed through the prism of the profane (primitive, joking): не поможе міцний Боже: тілько треба сажень землі, штири дошки, з неба спасення трошки.

In phraseological units, God is endowed with human attributes; he has вуха, ноги, руки, борода: піймати Бога за бороду (13 I,165), у руиі Божій (13 II, 775), Богу у вуха (13 II, 162), Бога піймав за ноги $(12,705)$, that differently categorize the world in an axiological dimension, in one case appealing to human conscience (nіймати Бога за бороду (13 I,165), and hoping in God in another one (у руціi Божій (13 II, 775).

\section{Binary oppositions of the concept of GOD in folklore discourse}

The dualistic opposition of God / gods would not be complete without consideration of the pre-Christian beliefs of Ukrainians, which objectifies the system of religious (world-view) directions aimed at knowing the world, its categorization, which is characterized by such features of archaic culture as cosmocentrism, polytheism. Already in the depths of paganism there was a tendency of domonotheization through the intermediate stage of the dual faith, the remains of which are still observed today. Paganism as a term used to refer to the pre-Christian religion of Ukrainians, it should be considered as the sum of the religious ideas of our ancestors, which Christianity caught in the VI - X centuries in the Slavic (Ukrainian) territories. It is at this time that the initial period of formation of the Ukrainian language probably accounts for the reason for the influence of paganism on the formation of the Ukrainian linguistic picture of the world. The ideological foundations of the Slavs date back to the ages and cannot be restricted to the I millennium AD. The prehistory of Kievan Rus was preceded by the isolation of the Middle Dnieper in the Skoloty-Scythian 
times of the VI - IV centuries BC; the Sarmatian time represented by the Zarubynets culture in the Kyievan Ros area; the Roman times (II - IV centuries AD) represented by the Ant-Chernyakhiv culture within the Kyivan-Rus region; the founding of the city of Kyiv in the V - VI centuries; the formation of the Dnieper Polyany-Rus-Siversk Union - the nucleus of Kyievan Rus in the VI-VII centuries in the Middle Dnieper and on the Left Bank. The influence of native speakers of different cultures has affected the religious pre-Christian beliefs of Ukrainians. Paganism as a religion brought to the Ukrainian language a deep layer of nouns to denote religious concepts, among which are nouns - theonyms.

It is known that our ancestors professed polytheism, although some scholars believe that in the last phase of paganism (the so-called first religious reform of Volodymyr), it evolved to monotheism ${ }^{1}$. Yes, GodFather of the Christian religion was answered in paganism by the godfather Strybog or Svarog, God-Son by god-son Dazhbog, Mother of God Makosha, the female deity, "mother of destiny", "mother of harvest". Having created such a pantheon, Volodymyr was able to have discussions with Christian missionaries, continuing the life of paganism as a religion. This pantheon looks rather sketchy and unproven because it has no place for other major pantheon gods. Although this idea does not seem so unfounded, the transformation of pagan deities is sporadically present in Christianity.

Theonym Perun is of Slavic origin; * Perun, associated with pbrati means"to beat, to strike", the original meaning of which is "the name of thunder," hereafter "god of thunder" (7 IV, 357). The word of this word is interesting in the Ukrainian language space. After the adoption of Christianity, it continues to mean "god of thunder", but gradually this meaning is out of use in the XV century. fixed only with the original meaning of "thunder" (9 II, 114). In the dictionary edited by B. Hrinchenko there are two meanings: "thunder", "the deity of the ancient Slavs" (8 III, 147). A dictionary of the Ukrainian language records the same meanings. M. Hrushevskiy believed that Perun, the god of thunder and lightning, took the first place in the pantheon of gods, though he suggested that the highest god of the Slavs might exist under another name (M. Hrushevskyi). I. Ohienko claimed Svarog as the highest god among our ancestors, and in relation to Perun, he first became the god of lightning and thunder, the ruler of the $\mathrm{sky}^{2}$. The conclusion of V.V. Ivanov and V.N. Toporov about the time of the cult of Perun-Thunderer is rather

\footnotetext{
${ }^{1}$ Рыбаков Б.А. Язычество древней Руси. М. : Наука, 1987. С. 433-454.

${ }^{2}$ Огієнко І.(Митрополит Іларіон). Дохристиянські вірування українського народу. К. : Обереги, 1992. C. 89 .
} 
interesting: "The (Thunderer) era can obviously be dated on the basis of such specific traits as the attributes of a myth hero (horse, chariot, bronze weapon, remnants of Thunderer's stone arrows... The appearance of these objects and their Indo-European names can be dated, probably, from the end of the third millennium $\mathrm{BC}^{3}$. "Later, he is the god of a military princely wife and army. Ye. Anichkov states that Perun was the chief god only of the princes of Kyiv, Rurik - Igorevich and his wife, and the merchants and peasants had their own gods. Ye. Anichkov argued that "the cult of Perun is a cult of the armed force and the princes of the Kiev Igorevichs, directly related to the birth of statehood and therefore a young, recent one" (quoted by:) ${ }^{4}$. The replacement of Perun by Illia occurred even before the baptism of Rus, when only part of the boyars of Kiev adopted Christianity. In Christian times, Perun is displaced by the prophet Illia, who rides through heaven in a chariot of fire. Judging by the fact that the feast of Illia (July 20) was celebrated very solemnly, and with all the signs of an ancient pagan cult, there is a reason to believe that it was this thunderous day which was a primordial day of Perun. Theonim Svarog is associated with the ancient Indian svargas "sky", the ancient German giswerc "rain clouds", with the Slavic свар (a) "arguing, punishing" (14 III, 568). In science it is not definitively established whether the Slavs understood the One God, because all the testimony speaks of them as polytheists. Perhaps in the beginning the only chief god was among our ancestors Svarog - the god of the sky, the sky himself and the light. He was the basis of everything, it is a god, the lord of the world. Svarog is the father of the sun and fire, from which all other gods have departed. Svarog was also regarded as the god of fire, so he is a guardian of blacksmithing and blacksmiths, as well as a guardian of craft, marriage and family happiness. As for blacksmithing, Saint Kuzma and Demyan became his patrons in Christianity instead of Svarog (memory of November 1-14). Our ancestors saw the chief, the "only god" of the creative power of all nature in Svarog. The cult of Svarog as the ruler of the ancient Slavic Olympus eventually declines and Perun is the one who takes over his functions.

Theonym Dazhbog is a composite formed from the Slavic *Dadjbbogъ, consisting of the imperative form of the verb *dadjь "and the basis of the noun bog" prosperity, wealth "with the meaning" pagan sun god "(7 II, 9). Since the XIV century this theonym has only meant a personal name. In the Ukrainian language of a later time there is a

\footnotetext{
${ }^{3}$ Иванов В.В., Топоров В.Н.Славянские языковые моделирующие семиотические системы. Древний период. М., 1974. С. 30.

${ }^{4}$ Рыбаков Б.А. Язычество древней Руси. М. : Наука, 1987. С. 434.
} 
rethinking of the components of this word in the phraseologisms in connection with the change of the religious paradigm, first of all, regarding the understanding of the theonym of god. In Dazhbog, our ancestors saw the ancient deity of nature, the sun, the god of "heaven", not "heaven." It is worth remembering that in ancient times the idea of a "celestial firmament" was very firmly rooted, dividing the whole above-ground space into two tiers: the upper tier contained "sky drains" (rainwater reserves), and in the lower one, under a giant dome, the sun went down, and the edge of the dome rested on the edge of the earth. The upper tier of the heavens over the firmament is the kingdom of the Strybog (Svarog, Rod). The lower tier with the sun and the earth is the kingdom of Dazhbog 5 .

Theonym Xors is of Iranian origin: Avestan hvare, Middle Persian xsaetem, New Persian xurset - "the sun that shines" (14 IV: 267). The word Xors meant god of the sun (sky), that is, the deity of the sun's light (but not light). Obviously, there was no independent value, but it was some addition to the image of Dazhbog-sun. Solar signs could also designate Xors as a specific daylight ("eye of light"), and be symbols of Dazhbog. It is likely that this is a very ancient deity, the idea of which was preceded by the ideas of the luminous heavenly sun. The cult of the sun-luminosity was clearly manifested among the Neolithic farmers, and as early as the Bronze Age, the idea of the night sun appeared, making its way underground in the "sea of darkness" 6 .

Theonym Volos (also known as Veles) is of Slavic origin, and apparently derived from Slavic * vels $-/ *$ vols-, associated with * volst "power", * voldeti "to own", the original meaning of which is "ancient pagan god of cattle" (7 I: 421). The Ukrainian language has preserved this root in the word володіти in the meanings: "to hold in power", "to own" (10 I: 191). Soon, this word acquired new meanings: "to be able to subjugate someone to their influence, their will"; "be able to act, use something"; "to be able to move parts of one's body" (10 I: 729). This root morpheme actively functions in words volodar (owner), volodarka (owner), volodarnyi, volodariuvannia, volodilets, volodilnyk, volodilnytsia, volodinnia (owning)The Ukrainian language picture of the world has not preserved this nomenclature for the designation of religious concepts. Volos was the god of wealth, animal cattle breeding. The expression of the idea of wealth with the help of the polysemantic word "cattle" (equivalent to Latin "pecunia" - "cattle", "wealth") suggests a certain historical bronze age, when the main wealth of the tribe were cattle,

\footnotetext{
${ }^{5}$ Рыбаков Б.А. Язычество древней Руси. М. : Наука, 1987. С. 444.

${ }^{6}$ Рыбаков Б.А. Язычество древней Руси. М. : Наука, 1987. С. 435.
} 
flocks of cattle. In Christian times, Volos was replaced by St. Vlasius, his day being celebrated on February 12th. He acted not only through phonetic harmony, but also through his way of life, because from his biography we know that St. Vlasius was a good shepherd, so he replaced the previous shepherd Veles (Volos), and became the patron saint of herds (stocks) ${ }^{7}$.

Theonym Strybog is borrowed, apparently, from the ancient Iranian language * Sribaya, meaning "the spiritualized god." This word is also considered as the Slavic * strojiti "builder (creator) of good", and as the German sterben "strive" and so on. (14 III, 777). The etymology of this theonym has not been established. Strybog was a god of the wind in the preChristian era. Although some scholars do not consider this theonym among the names of the gods, considering it the name of the tribe (Ye. Anichkov). In the teachings against paganism, the name of this deity is usually used alongside the name of Makosha, the "mother of the harvest".

Simargl (Semargl) theonym has not been etymologically clarified. There are several versions of its origin, but none are definitive. There is also a hypothesis about the presence of two deities, which are derived from this name Sim and Rogl. Scientists associate this theonym with the Latin, Greek, Pre Slavic, Pre Indo-European roots, without, however, establishing the original phonetic form (14 III, 622). Simargl is obviously a lower-order deity; it is also a sacred winged dog guarding seeds and crops. Already in the Trypillia painting there are dogs jumping and tossing (as if flying) around young plants. In those days, with the abundance of small cattle (roe deer, chamois, wild goats) the protection of crops from eating and trampling was an important thing. Simargl acted as the epitome of "armed good": in peaceful agrarian functions, he was endowed with claws, teeth, and wings; he is a crop protector. Later, the archaic Simargl became known as Pereplut ${ }^{8}$. He was associated with the roots of the plants. The cult of Simargl-Pereplut is closely associated with Russalias, holidays in honor of mermaids. Theonym Makosha is of Indo-European origin, related to the ancient Indian makhah - "rich, noble; demon", as well as with the orthodox mokrъ - "join the swamp". Theonym Makosha was used in the sense of "the ancient goddess of peace among the Slavs", "goddess of earth and fertility" (7 III, 367). The original seme of this word is difficult to determine, but the Slavic root mokr- is present in modern Ukrainian: mokryi, mokrota, mokrin, mokrity, mokrecha, mokruvatyi. Lexeme wet is an integral part of phrases: мокра курка - an indecisive person, miserable in appearance or a willless; мокра робота - crime; мокрого місця не

\footnotetext{
${ }^{7}$ Огієнко І.(Митрополит Іларіон). Дохристиянські вірування українського народу. К. : Обереги, 1992. C. 91.

${ }^{8}$ Рыбаков Б.А. Язычество древней Руси. М. : Наука, 1987. С. 444.
} 
залишити - nothing will be left; як мокре горить - something is done badly and very slowly; очі на мокрому місці - about a person who often cries. Obviously, the original meaning of this theonym is related to the ancient Indian root, but as early as in the early Christian period, this seme ceased to be associated with the name of the deity and got the meaning with which it functions today. In Christianity, Makosha was replaced by Paraskevia-Pyatnytsia. Other deities are also present in the pagan pantheon of gods: Rid, Rozhanytsia, Lada, Lel, Polel, Tur, Troian, Dolia (Destiny), Marena, Kara, Zhelia, Sviatovit and others, which are occasionally found in the chronicles, texts of the XI-XIV centuries, ethnographic materials of later times. Unfortunately, their origin, semantics, features of functioning are partially, and possibly completely lost for systematic research.

Paganism is also characterized by the worship of idols (kumyr,

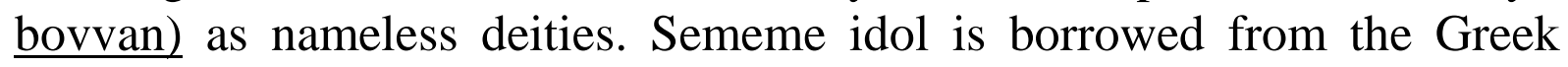
language. The original meaning of the word is "god, idol". The idols of our ancestors existed already in the III-IV centuries AD, in Skolotsk, Chernyakhivsk period in the Middle Podniprovvia. They built stone idols on trading roads, sacred sites and hills (73 I, 122-125). They were also made of wood and metal. The idol himself was a god for the heathen, not a reminder of God. As a rule, he had the appearance of a tall pillar with his head on it, sometimes dressed in clothes or decorated with spears and swords. Some of them were with a horn or bowl in their hand (the horn is a symbol of strength, the bowl means fate). Around them there were military items and flags, shields, spears, and more. Near the idol there were small figures, and behind them - large pillars that symbolized, apparently, the family of the pagan idol. Sememe idol is not recorded in lexicographic sources that represent the fourteenth and twentieth centuries, which is probably explained by the powerful Christian influence that superseded this notion, a characteristic ideologue in times of paganism?. The Dictionary of the Ukrainian Language provides a large word-forming series with the root idol-: idolka, idolovirets, idolovirka, idolovirstvo, idolianyn, idolianka, idolskyi (10 IV, 12-13). The appearance of these words is due, probably, to extralinguistic factors.

Lexeme bovvan is synonymous with lexeme idol. The word bovvan is borrowed from the Turkic languages: the ancient Turkic balbal means "tombstone, monument" (7 I, 218). It is used in the Ukrainian language with the meaning "statue depicting a god" and also with the figurative meaning "shallow-minded man" (10 I, 206). The primordial seme of this word is not part of the verbal sememe бовваніти, which stands for "be seen, shown from afar"; "to sit, to stand motionless," which testifies to the

${ }^{9}$ Рыбаков Б.А. Язычество древней Руси. М. : Наука, 1987. С. 391, 512-526. 
desemantization of the initial meaning of lexeme бовван. In the synonymic row of ідол, бовван a special place is occupied by the seme кумир with the similar semantics "the statue which the pagans worship as a deity" (10 I, 206). In this constituent, in one of the lexico-semantic variants, the meaning of "one who serves the object of admiration, worship" has developed. Positive connotation is not a typical language phenomenon for pagan people. A special place was given to demonic beings, among whom the word русалка underwent the greatest religious transformations. The nomen mermaid is borrowed from the Middle Greek, which means "trinity" or from the Latin language rosalia "holiday of roses". Among our ancestors, it functioned in two respects: "the pagan holiday of spring", "the game of this holiday - Rusalia". With the onset of spring, русалки (mermaids) come to life, but still live in the dark depths of the earth's waters, still cold in the spring. Mermaids are fun, mischievous and addictive creatures that sing songs in beautiful and engaging voices. In the image of mermaids, folk fantasy combines the idea of water and forest maidens: mermaids love to swing on wooden branches, they are filled with evil laughter and tickle to death the careless traveler. Mermaids (rusalkas or vilas) were depicted as sirens - beautiful winged birds and were considered of irrigation in the fields, rain or wet morning fogs. The holidays of Rusalia were celebrated at the beginning and end of winter holidays ("in the evenings of Christmas and Epiphany"), framing annual spells of nature and fate by praying for water - a prerequisite for the future harvest. Subsequently, the word mermaid gained the meaning of "holiday of the Trinity" and functioned with this nomen of mermaid Easter. Responses of polytheism are also found in phraseological constructions that function actively in the modern linguistic consciousness: боги би тя побили $(6,68)$, кланятися чужим богам, мавши свої! $(12,235)$. In some phraseological units, the binary opposition to God / gods is realized only by the second member of the opposition in the Ukrainian linguistic consciousness: чужих богів шукає, а свойх дома має (12, 235); за малим богом (13 I, 42); як боги (13 I,42); бог Мамона обплутав (13 I, 38).

\section{CONCLUSIONS}

In the semantic opposition of God/man the categorization of the concepts of good/evil, positive/negative relates mainly to the human being and is beyond the sacred. The outlined semantic opposition is objectified by the attitude of God towards father, master, guest, orphan; idlers, drunkards, fools and others. The first are patronized by God, the rest are condemned. Although the first and second categories of people have a kind of protection from God (сиріт Бог любить, але щзастя недає; дурневі ж 
дає Бог щзастя, а не дає розуму). As for the human virtues which God appreciates, it is primarily spiritual - righteousness, justice, kindness, sincerity, gentleness. Sharp negation manifests itself in such traits as pride, anger, envy, etc.

Family life is governed by God's precepts, which are based on monogamy, faithfulness in marriage, which is fixed in heaven and is more often broken by men (Бог за жінку, а чоловік за дівку), although "compassion" in marriage is more often received by a man ( $и$ maк багато всякого лиха, а Бог ще жінок сотворив). The version of family relationships, reflected in the Ukrainian paremias, differs significantly from the Christian understanding of family, by which husband and wife form spiritual unity equal to God.

The phraseological units under study regarding the semantic opposition to God/ death of man do not provide grounds for categorization into physical and spiritual death, although the fear of death has been verbalized by a large number of established utterances. In part, the word "fear" is counteracted by a verbal joke. In general, humor is the hallmark of many GODs. Binary opposition to God/gods is rather fragmentary in folklore genres, with the exception of the chronicle sources of the $\mathrm{X}$ - XIII centuries, on the basis of which the pagan pantheon of gods and its influence on the formation of the Ukrainian linguistic picture of the world (linguistic, religious) were investigated. In the following centuries, this influence was minimized due to the Christianization of society, the global change in the religious outlook of Ukrainians. Of the gods of paganism, only Perun was preserved in folklore discourse, likened to the God of Christianity. A considerable number of pre-Christian gods were transformed into Christian saints (Svarog - into saints Kuzma and Demian, Volos - into Saint Vlasii, Makosha - into Saint Paraskevia, etc.). They were given new names, but they continued to be worshipped. Many folk customs have acquired a Christian coloring. The Christian culture continued this coexistence, partially assimilating them, but not completely displacing them. This explains the wide variety of folk beliefs represented in the folklore discourse, which attests to a peculiar religious phenomenon - the dual faith.

\section{SUMMARY}

The monograph explores the religious ethno-consciousness of Ukrainians in the context of cultural and historical oppositions - God's qualities / human qualities, God / gods. The Ukrainian phraseological and paremological fund, which reflects people's ideas about God, is analyzed. We ascertain the evolution of religious views of Ukrainians: polytheism, 
diocese, monotheism (Christianity). These religious manifestations coexist in some way in the popular consciousness, creating a religious picture of the world of Ukrainians.

The semantic opposition of God/ man is considered based on the categorization of the concepts of good/evil, positive/negative This semantic opposition is objectified by the attitude of God tofather, master, guest, orphan; idlers, drunkards, fools.

The pagan pantheon of gods and its influence on the formation of the Ukrainian linguistic picture of the world (linguistic, religious), which is minimized by the Christianization of society, the global change in the religious outlook of Ukrainians, are outlined. Of the gods of paganism, only Perun was preserved in folklore discourse, likened to the God of Christianity. A considerable number of pre-Christian gods were transformed into Christian saints (Svarog - into saints Kuzma and Demian, Volos - into Saint Vlasii, Makosha - into Saint Paraskevia, etc.). They were given new names, but they continued to be worshippd. Many folk customs have acquired a Christian coloring.

\section{REFERENCES}

1. Грушевський М.С. Репринтне видання: Історія України-Руси: В 12 т., 12 кн. // Редкол.: П.С. Сохань (голова) та ін. К., 1991. Т. 1. $648 \mathrm{c}$.

2. Иванов В.В., Топоров В.Н. Славянские языковые моделирующие семиотические системы.Древний период. М., 1974. 248 с.

3. Огієнко I. (Митрополит Іларіон). Дохристиянські вірування українського народу. К.: Обереги, 1992. 342 с.

4. Рыбаков Б.А. Язычество древней Руси. М.: Наука, 1987. 783 с.

\section{SOURCES OF ILLUSTRATIVE MATERIAL}

1. Біблія або Книги Святого Письма Старого й Нового Заповіту із мови давньоєврейської та грецької на українську наново перекладена. Переклад І. Огієнка, 1962 р.

2. Галицько-руські народні приповідки / Зібрав, упорядкував i пояснив Іван Франко. Львів, 1901-1909. Т. 1-3.

3. Етимологічний словник української мови: В 7-ми т. К., 1982. 2003. Т. 1-6.

4. Словарь української мови / Упорядник з дод. влас. матеріалу Б.Д. Грінченко. К., 1907-1909. Т. 1-4.

5. Словник староукраїнської мови XIV - XV ст.: В 2-х т. К., 1977. $978 \mathrm{c.}$

6. Словник української мови: В 12-ти т. К., 1970-1980. 
7. Тимченко $€$. Матеріали до словника писемної та книжної української мови XV - XVIII століть: Книга 1, 2. Київ, Нью-Йорк, 2002.

8. Українські приказки, прислів'я, і таке інше. Уклав М. Номис. Київ:Либідь, 1993. 768 с.

9. Фразеологічний словник української мови. У 2-х томах. 2-е вид. Кн. 1-2. К.: Наук. думка, 1999. 980 с.

10. Фасмер М. Этимологический словарь русского языка: В 4-х т. M., 1964-1973.

\section{Information about the author:} Matskiv P. V.,

Doctor of Philological Sciences, Professor, Head of the Department of the Ukrainian Language, Drohobych Ivan Franko State Pedagogical University 22, U. Kravchenko str., Drohobych, 82100, Ukraine 